\title{
Note on "Fines" for the Damage of Books."
}

MOST Lending Libraries have a regulation somewhat to M this effect: that each book on its return shall be examined by the librarian, and, if it be found to have sustained any damage, the borrower shall be held accountable for the same.

It may be at once admitted that there is a certain kind of damage to which this rule can be applied without hesitation -the kind, namely, where the effects of the damage are of so glaring a nature that they cannot fail to catch the eye of even the busiest librarian, and for which not even the most unblushing of borrowers would venture to dispute his liability. The case, however, is altogether different in those instances -and they are, unfortunately, far the more frequent-in which the damage is of a less conspicuous, and of a more or less elusive, character. Such are the instances of tearing of leaves and plates, or their complete removal from the volumes, of stains from ink and other even more objectionable liquids, and of written marks and comments of a more or less offensive order. These, for the most part, are only to be detected by a very careful, deliberate, and in some cases, page-by-page examination. Such an examination it is clearly impossible for the librarian to make on the return of each volume; and yet without it how can he fairly keep the balance of blame between successive borrowers, and, at the same time, conserve the interests and property of the library? Looked at in any way, the problem presents difficulties, which the librarian who would do justly finds a daily source of perplexity. As the result of my own experience, the solution which presents itself as at once reasonable and fair, is to throw the burden of detection of damage on the borrower. $\mathrm{He}$ is the one who alone is in a good position to discover blemishes of the kind in question, and it should be made to seem both his duty and his interest to take the earliest opportunity to direct the librarian's atten-

- Read at the Annual Meeting of the Library Association, Nottingham, September, I8gr. 
tion to whatever of that nature he comes across. If he fail to do this, there should then be a prima facie case against him as the offender. Of course, cven though he does do so, it does not necessarily follow that he is innocent, for he may be a dishonest person, trying to cover up his own iniquity by imputing blame to another; or he may be an innocent sufferer for damage not done by himself, but done while the book was in his charge, by his messenger, or some member of his household. In any case, however, much, if not everything, has been gained in the cause of the detection of damagc, and we are put in a fair way to fix the penalty on the right party. In concluding this brief note, I append a copy of a notice to borrowers, which is now inserted in the volumes of the Aberdeen Public Library, immediately before the text proper, and which embodies the principle now set forth.

\section{Aberdeen Public Library.}

Borrowers are requested to note that it is both their duty and their interest to use Library Volumes with all possible care, and to protect them while in their keeping from any harm which would tend to lessen their value or pleasure to other Borrowers. Care is taken, as far as possible, by the Librarian to see that all Books are complete and in good order at the time of issue ; but, for various reasons, many blemishes must needs escape notice. It is incumbent, therefore, on every Borrower to examine, as soon as possible, all Books intrusted to him, and if then or subsequently in reading he should discover any defect or damage, he should take the earliest opportunity to report the same at the Library. Any Borrower who fails to do this is liable to be charged with the defect or damage, and to have his Ticket suspended.

Borrowers who accidentally injure Books, or suffer them to be injured, should, on the return of the same to the Library, draw the Librarian's attention to the injury, otherwise their Tickets will be suspended, and their conduct reported to the Library Committee.

Borrowers who, by writing, tearing, or in any other way wilfully injure Books, or suffer them to be wilfully injured, will be regarded as unfit to use the Library, and be dealt with accordingly.

By order,

A. W. ROBERTSON, M.A., Librarian. 